\title{
Riparsaponin isolated from Homonoia riparia Lour induces apoptosis of oral cancer cells
}

\author{
TIECHENG $\mathrm{LI}^{1}$ and LEI WANG ${ }^{2}$ \\ ${ }^{1}$ Department of Stomatology, Daqing Oilfield General Hospital, Daqing, Heilongjiang 163000; \\ ${ }^{2}$ Department of Stomatology, Daqing LongNan Hospital, Daqing, Heilongjiang 163453, P.R. China
}

Received May 31, 2016; Accepted July 21, 2017

DOI: $10.3892 / \mathrm{ol} .2017 .7043$

\begin{abstract}
Homonoia riparia Lour (Euphorbiaceae) is a known source of herbal medicine in China, and riparsaponin (RSP) is an active constituent isolated from $H$. riparia. The aim of the present study was to investigate the antitumor effect of RSP on human oral carcinoma cells and its potential underlying molecular mechanism. RSP was isolated from roots of $H$. riparia and identified using nuclear magnetic resonance. An MTT assay was used to evaluate the cytotoxicity of RSP on human oral carcinoma cells. Subsequently, DAPI staining was performed to investigate the apoptotic effect of RSP. To investigate the potential underlying molecular mechanism of action of RSP, western blotting was performed to determine the expression of cleaved caspase 3/9, B-cell lymphoma 2 (Bcl-2), Bcl-2-associated X protein (Bax), Bcl-2-associated death promoter (Bad), epithelial cadherin (E-CAD), c-MET, matrix metalloproteinase (MMP)-2 and MMP-9. RSP exhibited a significant anti-proliferative effect on oral carcinoma cells at concentrations between 10 and $200 \mu \mathrm{g} / \mathrm{ml}$ via apoptosis. Following treatment with RSP (20,40 and $80 \mu \mathrm{g} / \mathrm{ml})$, expression of cleaved caspase- $3(\mathrm{P}<0.05, \mathrm{P}<0.01$ and $\mathrm{P}<0.01$, respectively), cleaved caspase-9 $(\mathrm{P}<0.01)$, Bad $(\mathrm{P}<0.01)$, Bax $(\mathrm{P}<0.01)$, c-MET $(\mathrm{P}<0.01)$, MMP-2 $(\mathrm{P}<0.01)$ and MMP-9 $(\mathrm{P}<0.01)$ in oral carcinoma cells was increased significantly compared with the control group, whereas expression of Bcl-2 $(\mathrm{P}<0.01)$ and E-CAD $(\mathrm{P}<0.01)$ was decreased. These results suggest that RSP possessed notable antitumor activity against oral squamous cell carcinoma by inducing mitochondria-mediated apoptosis.
\end{abstract}

\section{Introduction}

It is reported that oral squamous cell carcinoma (OSCC), one of the most common oral malignancies of the squamous epithelium

Correspondence to: Dr Lei Wang, Department of Stomatology, Daqing LongNan Hospital, 35 Aiguo Road, Daqing, Heilongjiang 163453, P.R. China

E-mail: wangleidahp@yeah.net

Key words: mitochondria-mediated apoptosis, herbal medicine, oral squamous cell carcinoma, caspase of the oral cavity, is the sixth most common type of cancer globally (1-3). It has been reported that developing countries have the highest incidence rates of OSCC and it is expected that the incidence will continue to increase (4); furthermore, OSCC commonly occurs in middle-aged and elderly males because of tobacco and alcohol use (5). OSCC commonly occurs in the tissues of the oral cavity, including the gingiva, tongue, lip, hard palate, buccal mucosa and mouth floor $(4,6)$. OSCC exhibits a marked propensity for invasive growth and metastasis, leading to damage of the original tissues or that of distant organs $(2,4)$. The predominant treatment strategy for OSCC is radical surgery and postoperative chemoradiation (4). Marked improvements have been made in clinical diagnosis and management of OSCC; however, high recurrence rates and low 5-year survival rates have remained constant for several decades (7).

Increasingly, previous studies have revealed that chemotherapy using natural agents with low toxicity is a promising approach for treating various types of cancer (8-10). In addition, traditional Chinese medicine (TCM) has been used in the treatment of various incurable diseases for centuries, and the reliability and effectiveness of TCMs have been demonstrated by long-term clinical use in China $(11,12)$. Homonoia riparia Lour (Euphorbiaceae), is a known source of TCM with antipyretic and detoxification functions, and is commonly used as an effective agent for treating infection, hepatitis, hemorrhoids, ulcers, tumor and ambustion (13-15). Riparsaponin (RSP; Fig. 1) is an active constituent isolated from $H$. riparia that possesses potential for treating gouty arthritis (16). In the present study, the antitumor effects of RSP on human oral carcinoma cells via the induction of apoptosis were systematically investigated, which has reference value for the clinical use of RSP in the treatment of OSCC.

\section{Materials and methods}

Plant materials. The roots of $H$. riparia were purchased from the Juhuacun Market of Traditional Chinese Herbs (Kunming, China) in October 2014, and were identified by the Department of Chinese Herbal Medicine in the Daqing Oilfield General Hospital (Daqing, China). A voucher specimen of this plant was deposited in the department of Stomatology laboratory, Daqing Oilfield General Hospital (reference no. S-hptcm-20141007). 
Chemicals and reagents. Dulbecco's modified Eagle's medium (DMEM), fetal bovine serum (FBS), and anti-epithelial cadherin (E-CAD) (1:2,000; cat. no. 13-1700) and -c-MET $(1: 2,000$; cat. no. 44-888G) antibodies were purchased from Invitrogen; Thermo Fisher Scientific, Inc. (Waltham, MA, USA). MTT, DAPI and dimethyl sulfoxide (DMSO) were purchased from Sigma-Aldrich; Merck KGaA (Darmstadt, Germany). Antibodies against cleaved caspase-3/9 (C-caspase-3/9) (1:2,000; cat. nos. 9664 and 7237, respectively), matrix metalloproteinase (MMP)-2 (1:2,000; cat. no. 87809) and MMP-9 (1:2,000; cat. no. 13667) were purchased from Cell Signaling Technology,Inc. (Danvers, MA,USA). Antibodies against B-cell lymphoma 2 (Bcl-2) (1:1,000; cat. no. AB112), Bcl-2-associated $\mathrm{X}$ protein (Bax) (1:1,000; cat. no. AB026), Bcl-2-associated death promoter (Bad) $(1: 1,000$; cat. no. AB008) and $\beta$-actin (1:1,000; cat. no. AB128), goat anti-rabbit horseradish peroxidase (HRP)-conjugated secondary antibodies (1:1,000; cat. no. A0208), the enhanced chemiluminescence reagent and cell lysis buffer for Western and IP kit were purchased from Beyotime Institute of Biotechnology (Haimen, China). All other chemicals used in the present study were of analytical reagent grade.

Cell culture. Human oral carcinoma cell lines (Cal-27, SCC-9 and Detroit 562) were purchased from the American Type Culture Collection (Manassas, VA, USA), and the human embryonic lung fibroblast cell line MRC-5 was purchased from Cellcook Biotech. Co., Ltd. (Guangzhou, China). Cells were cultured in DMEM supplemented with $10 \%$ FBS, $100 \mathrm{U} / \mathrm{ml}$ penicillin and $100 \mu \mathrm{g} / \mathrm{ml}$ streptomycin at $37^{\circ} \mathrm{C}$ in a humidified incubator containing $5 \% \mathrm{CO}_{2}$.

Preparation of RSP. Dried roots of $H$. riparia were powdered and extracted with $60 \%$ ethanol under reflux. Then, the extracts were sequentially extracted with petroleum ether, ethyl acetate and n-butanol to produce petroleum ether fraction, ethyl acetate fraction (AE), n-butanol fraction and water fraction. The AE was subjected to column chromatography (CC) over a silica gel (200-300 mesh), eluting with ethyl acetate-acetone (20:1, 15:1, 10:1, 5:1, 3:1 and 1:1) to yield four subfractions I-IV on the basis of the results of thin layer chromatography (TLC) analysis: The aforementioned CC elution samples (3 $\mu \mathrm{l})$ were analyzed using silica gel $\mathrm{G}$ thin layer plate, and the chromatography was run for $8 \mathrm{~cm}$ using an ethyl acetate-acetone mobile phase (10:1, 5:1 and 2:1) and the TLC spots were visualized using 10\% sulfuric acid alcohol chromogenic agent. Fraction III was repeatedly subjected to CC over a silica gel (200-300 mesh), eluting with ethyl acetate-acetone (15:1, 10:1, 5:1, 3:1 and 1:1) to yield four subfractions $\mathrm{III}_{1}-\mathrm{III}_{4}$. RSP was crystallized from $\mathrm{III}_{2}$.

The isolated RSP was identified by ${ }^{1} \mathrm{H}$-nuclear magnetic resonance (NMR) and ${ }^{13} \mathrm{C}-\mathrm{NMR}$, and compared with results of previous studies $(13,16)$. The ${ }^{1} \mathrm{H}-\mathrm{NMR}$ and ${ }^{13} \mathrm{C}-\mathrm{NMR}$ spectral data of this compound are as follows: ${ }^{1} \mathrm{H}-\mathrm{NMR}(500 \mathrm{MHz}$, $\left.\mathrm{CDCl}_{3}\right) \delta$ (ppm): 0.32, 0.92 (2 H, m, H-19), $3.11(1 \mathrm{H}, \mathrm{m}, \mathrm{H}-3)$, $4.71\left(2 \mathrm{H}\right.$, brs, H-31), 0.84, (3 H, d, J $\left.8.1 \mathrm{~Hz}, 21-\mathrm{CH}_{3}\right), 0.90(3 \mathrm{H}$, s, 28- $\left.\mathrm{CH}_{3}\right), 0.93\left(3 \mathrm{H}, \mathrm{s}, 26-\mathrm{CH}_{3}\right), 0.95\left(3 \mathrm{H}, \mathrm{s}, 27-\mathrm{CH}_{3}\right), 1.02$ ( $\left.3 \mathrm{H}, \mathrm{s}, 29-\mathrm{CH}_{3}\right), 1.09\left(3 \mathrm{H}, \mathrm{s}, 30-\mathrm{CH}_{3}\right), 1.17\left(3 \mathrm{H}, \mathrm{s}, 18-\mathrm{CH}_{3}\right)$; ${ }^{13} \mathrm{C}-\mathrm{NMR}\left(125 \mathrm{MHz}, \mathrm{DMSO}-\mathrm{d}_{6}\right.$ ) $\delta$ (ppm): 30.97 (C-1), 29.25 (C-2), 88.97 (C-3), 42.19 (C-4), 48.91 (C-5), 71.90 (C-6), 71.04

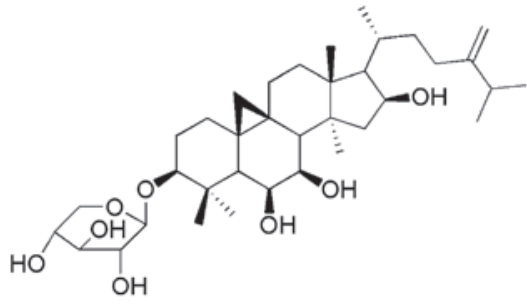

Figure 1. Chemical structure of riparsaponin isolated from H. riparia.

(C-7), 46.03 (C-8), 25.14 (C-9), 18.87 (C-10), 26.99 (C-11), 33.07 (C-12), 45.81 (C-13), 45.00 (C-14), 51.03 (C-15), 71.13 (C-16), 58.31 (C-17), 21.61 (C-18), 32.04 (C-19), 28.10 (C-20), 18.04 (C-21), 37.03 (C-22), 32.82 (C-23), 160.07 (C-24), 34.21 (C-25), 22.52 (C-26), 24.01 (C-27), 20.13 (C-28), 24.82 (C-29), 16.88 (C-30), 109.27 (C-31), 105.01 (C-1'), 73.26 (C-2'), 78.38 (C-3'), 67.05 (C-4'), 68.93 (C-5').

Determination of cell viability. Cell viability was determined using the MTT assay. Briefly, cells $\left(1 \times 10^{5}\right.$ cells $\left./ \mathrm{ml}\right)$ were plated in 96-well plates for $24 \mathrm{~h}$. Subsequently, cells were treated with RSP at various concentrations $(0,5,10$, $20,40,80,150$ and $200 \mu \mathrm{g} / \mathrm{ml}$ ) for $24 \mathrm{~h}$. Subsequently, an MTT assay was used to determine the cell viability $(n=4)$, and the optical density value was determined at $570 \mathrm{~nm}$ on a microplate reader (Bio-Rad Laboratories, Inc., Hercules, CA, USA).

Nuclear staining with DAPI. A DAPI staining assay was carried out for the apoptosis assays. Briefly, cells were exposed to RSP for $24 \mathrm{~h}$ at $37^{\circ} \mathrm{C}$, and then cells were stained with DAPI at room temperature for $5 \mathrm{~min}$. Alterations in the cell nuclei were determined using fluorescence microscopy (Olympus Corporation, Tokyo, Japan) at magnification, x200.

Western blot analysis. Following treatment with RSP $(0,20$, 40 and $80 \mu \mathrm{g} / \mathrm{ml}$ ) for $24 \mathrm{~h}$ at $37^{\circ} \mathrm{C}$, cells were harvested and total proteins were extracted by using the Cell lysis buffer for Western and IP kit according to manufacturer's protocol. The concentration of protein was determined using a bicinchoninic acid protein assay kit. Equal amounts of protein $(30 \mu \mathrm{g})$ were separated by SDS/PAGE (12\% gel), then transferred onto a PVDF membrane and probed with various primary antibodies overnight at $4{ }^{\circ} \mathrm{C}$, followed by incubation with HRP-conjugated secondary antibodies for $1 \mathrm{~h}$ at room temperature. Finally, the protein bands were visualized using chemiluminescence detection with the enhanced chemiluminescence reagent. Densitometric determination of the blots was carried out using Quantity One software (version 4.0; Bio-Rad Laboratories). To normalize protein loading, antibodies against $\beta$-actin were used, and the protein level was expressed as a value relative to that of $\beta$-actin.

Statistical analysis. All data are expressed as the mean \pm standard deviation, and the significance of the differences between groups was determined using one-way analysis of variance with SPSS for Windows software (version 19.0; IBM Corp., Armonk, NY, USA). $\mathrm{P}<0.05$ was considered to indicate a statistically significant difference. 


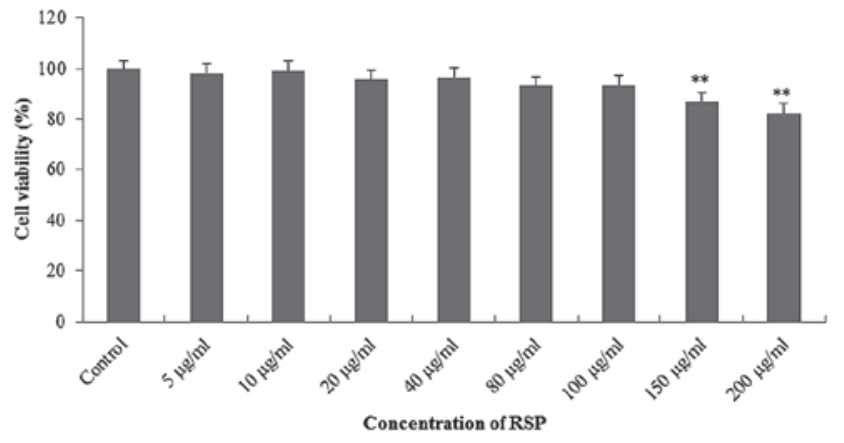

Figure 2. Cytotoxic effect of RSP on MRC-5 cells in vitro. Cells were treated with RSP at various concentrations $(0,5,10,20,40,80,100,150$ and $200 \mu \mathrm{g} / \mathrm{ml}$ ) for $24 \mathrm{~h}$. An MTT assay was used to determine cell viability $(n=4) .{ }^{* *} \mathrm{P}<0.01$ vs. control. RSP, riparsaponin.

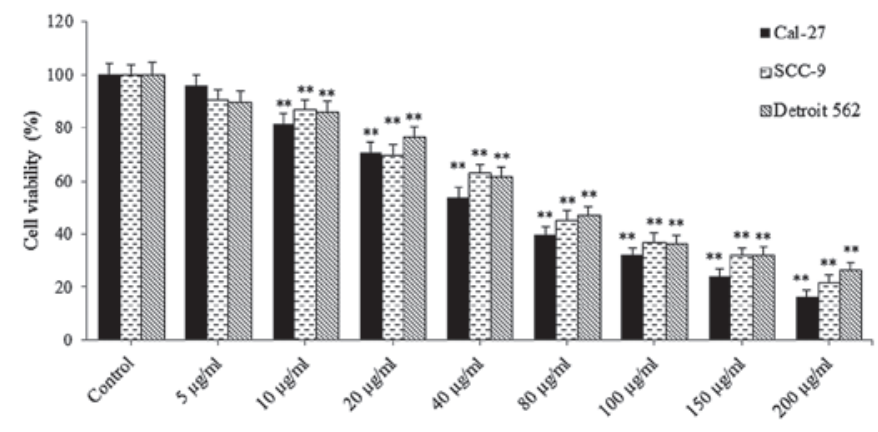

Figure 3. Cytotoxic effects of RSP on Cal-27, SCC-9 and Detroit cells in vitro Cells were treated with RSP at various concentrations $(0,5,10,20,40,80$, 100,150 and $200 \mu \mathrm{g} / \mathrm{ml}$ ) for $24 \mathrm{~h}$. An MTT assay was used to determine cell viability $(n=4) .{ }^{* *} \mathrm{P}<0.01$ vs. control. $\mathrm{RSP}$, riparsaponin.

\section{Results}

Inhibitory effects of RSP on MRC-5 cell and oral cancer cells in vitro. For investigating the toxicological effect of RSP, the human embryonic lung fibroblast cell line MRC-5 was used. No significant cytotoxic effect of RSP on MRC-5 cells was observed at concentrations $<100 \mu \mathrm{g} / \mathrm{ml}$ compared with the control (Fig. 2).

Furthermore, the cytotoxic effects of RSP on three human oral carcinoma cell lines (Cal-27, SCC-9 and Detroit 562 cells) were evaluated. RSP exhibited a marked anti-proliferative effect on the three oral cancer cell lines, which was concentration-dependent between 10 and $200 \mu \mathrm{g} / \mathrm{ml}$ (Fig. 3).

Pro-apoptotic effect of RSP on SCC-9 cells. Results of the cytotoxicity assay indicated that RSP exerts significant antitumor potential on human oral carcinoma cells. Furthermore, in order to determine whether the antitumor effect of RSP was due to apoptosis, DAPI, a widely used cell-permeant DNA dye, was used to stain SSC-9 cells for observing the nuclear morphological changes (Fig. 4). The results indicated that the cell nuclei in the control group were round and normal with faint staining (cells were alive). By contrast, following treatment with RSP at concentrations of 20,40 and $80 \mu \mathrm{g} / \mathrm{ml}$, characteristic features of apoptosis were observed, including typical nuclear condensation, increased brightness and nuclear fragmentation. These results revealed that RSP induced SSC-9 cell death due to apoptosis.
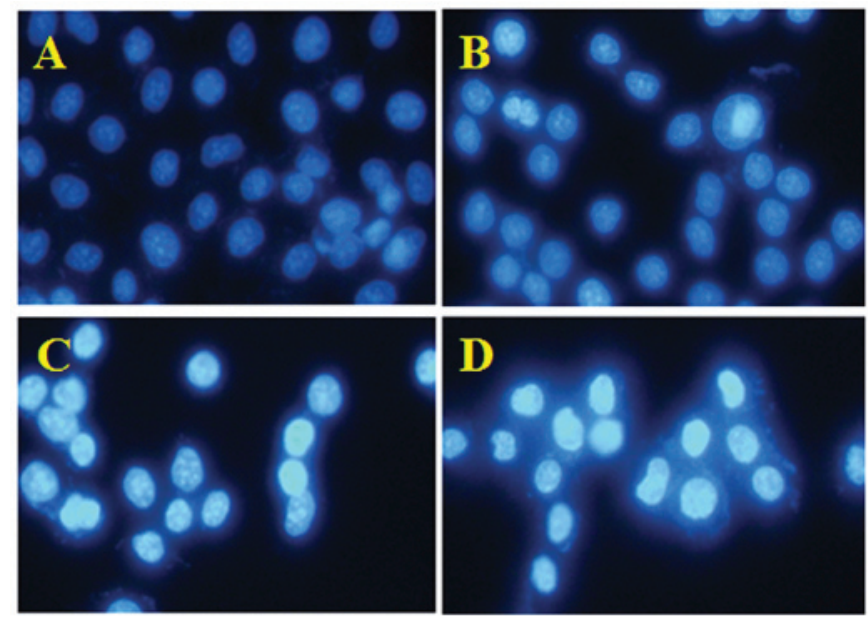

Figure 4. RSP induces apoptosis in SCC-9 cells. Cells were treated with RSP at 20,40 and $80 \mu \mathrm{g} / \mathrm{ml}$ for $24 \mathrm{~h}$, and apoptotic cells were detected by DAPI staining and visualized using a fluorescence microscope (magnification, x200). (A) Control (untreated cells). Cells treated with RSP at (B) 20, (C) 40 and (D) $80 \mu \mathrm{g} / \mathrm{ml}$, respectively. RSP, riparsaponin.
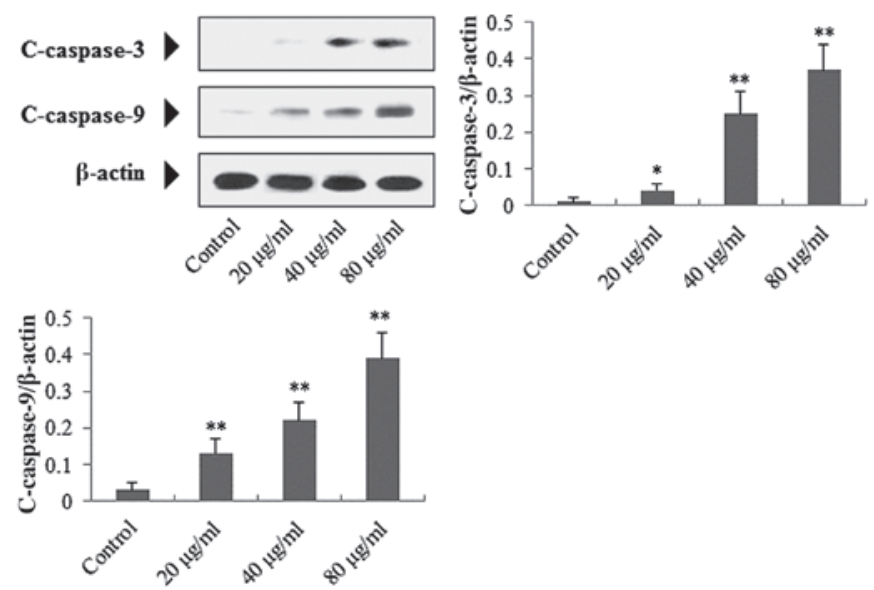

Figure 5. Effects of RSP on caspase family protein expression in SCC-9 cells. Cells were treated with RSP $(20,40$ and $80 \mu \mathrm{g} / \mathrm{ml})$ for $24 \mathrm{~h}$. Total cell proteins were extracted and subjected to western blot assay using antibodies against C-caspase-3 and C-caspase-9, with $\beta$-actin used as an internal control. Results are expressed as the mean \pm standard deviation $(n=4)$. ${ }^{*} \mathrm{P}<0.05,{ }^{* *} \mathrm{P}<0.01$ vs. control. RSP, riparsaponin; $\mathrm{C}-$, cleaved.

RSP upregulates C-caspase-3, C-caspase-9, Bad and Bax, and downregulates $\mathrm{Bcl}-2$ in SCC-9 cells. To investigate the potential apoptotic mechanism induced by RSP in SSC-9 cells, the expression levels of associated mitochondria-mediated intrinsic apoptosis proteins were determined using western blotting. As presented in Figs. 5 and 6, following treatment with $\mathrm{RSP}(20,40$ and $80 \mu \mathrm{g} / \mathrm{ml})$, expression of C-caspase-3 $(\mathrm{P}<0.05$, $\mathrm{P}<0.01$ and $\mathrm{P}<0.01$, respectively), C-caspase-9 $(\mathrm{P}<0.01), \mathrm{Bad}$ $(\mathrm{P}<0.01)$ and $\mathrm{Bax}(\mathrm{P}<0.01)$ in $\mathrm{SSC}-9$ cells were significantly increased compared with the control group, whereas Bcl-2 expression $(\mathrm{P}<0.01)$ was decreased.

RSP downregulates $c-M E T, M M P-2$ and MMP-9, and upregulates E-CAD in SCC-9 cells. As presented in Figs. 7 and 8 , following treatment with $\operatorname{RSP}(20,40$ and $80 \mu \mathrm{g} / \mathrm{ml})$, expression levels of c-MET $(\mathrm{P}<0.01)$, MMP-2 $(\mathrm{P}<0.01)$ and 

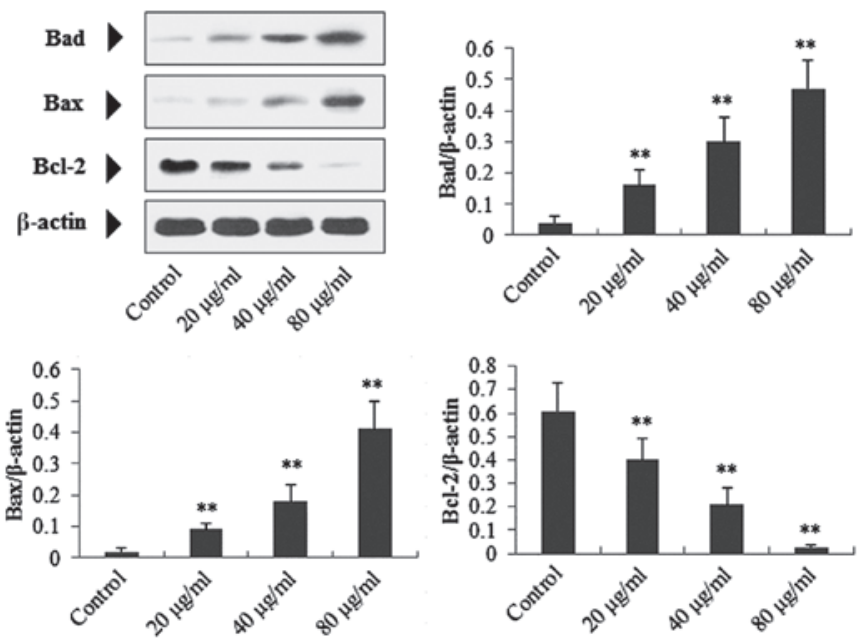

Figure 6. Effects of RSP on Bcl-2 family protein expression in SCC-9 cells. Cells were treated with RSP $(20,40$ and $80 \mu \mathrm{g} / \mathrm{ml})$ for $24 \mathrm{~h}$. Total cell proteins were extracted and subjected to western blot assay using antibodies against Bcl-2, Bad and Bax, with $\beta$-actin used as an internal control. Results are expressed as the mean \pm standard deviation $(\mathrm{n}=4)$. ${ }^{* *} \mathrm{P}<0.01$ vs. control. RSP, riparsaponin; Bcl-2, B-cell lymphoma 2; Bad, Bcl-2-associated death promoter; Bax, Bcl-2-associated $\mathrm{X}$ protein.
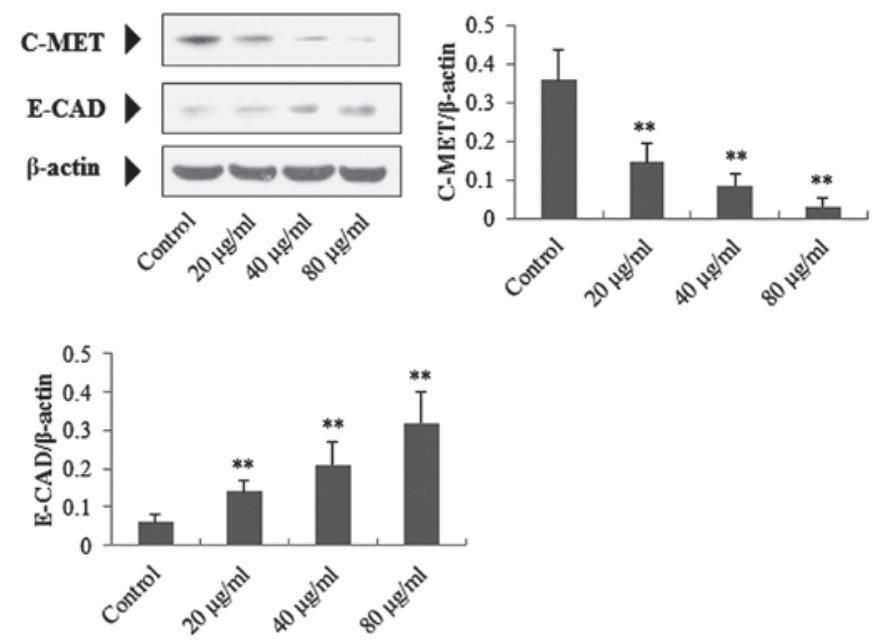

Figure 7. Effects of RSP on E-CAD and c-MET protein expression in SCC-9 cells. Cells were treated with RSP $(20,40$ and $80 \mu \mathrm{g} / \mathrm{ml})$ for $24 \mathrm{~h}$. Total cell proteins were extracted and subjected to western blot assay using antibodies against E-CAD and c-MET, with $\beta$-actin used as an internal control. Results are expressed as the mean \pm standard deviation $(n=4) .{ }^{* *} \mathrm{P}<0.01$ vs. control. RSP, riparsaponin; E-CAD, epithelial cadherin.

MMP-9 $(\mathrm{P}<0.01)$ in SSC-9 cells were significantly decreased compared with the control group, whereas the expression of E-CAD $(\mathrm{P}<0.01)$ was increased.

Regulatory effects of RSP on the expression of $C$-caspase-3, Bad, Bcl-2, c-MET, E-CAD and MMP-9 in Cal-27 cells. The regulatory effects of RSP on caspase-3, Bax, Bcl-2, c-MET, E-CAD and MMP-9 in Cal-27 cells were determined. Similar to SCC-9 cells, it was identified that RSP significantly downregulated protein expression of Bcl-2 $(\mathrm{P}<0.01)$, c-MET $(\mathrm{P}<0.01)$ and MMP-9 $(\mathrm{P}<0.01)$, whereas protein expression of C-caspase-3 ( $\mathrm{P}<0.01)$, Bax $(\mathrm{P}<0.01)$ and $\mathrm{E}-\mathrm{CAD}(\mathrm{P}<0.01)$ was
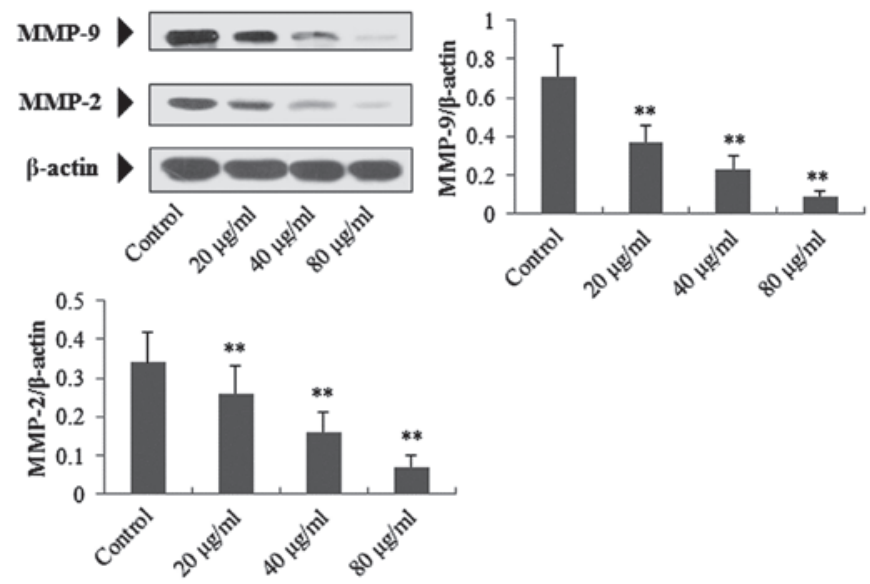

Figure 8. Effects of RSP on MMP protein expression in SCC-9 cells. Cells were treated with RSP $(20,40$ and $80 \mu \mathrm{g} / \mathrm{ml})$ for $24 \mathrm{~h}$. Total cell protein were extracted and subjected to western blot assay using antibodies against MMP-2 and MMP-9, with $\beta$-actin used as an internal control. Results are expressed as the mean \pm standard deviation $(n=4)$. ${ }^{* *} \mathrm{P}<0.01$ vs. control. RSP, riparsaponin; MMP, matrix metalloproteinase.
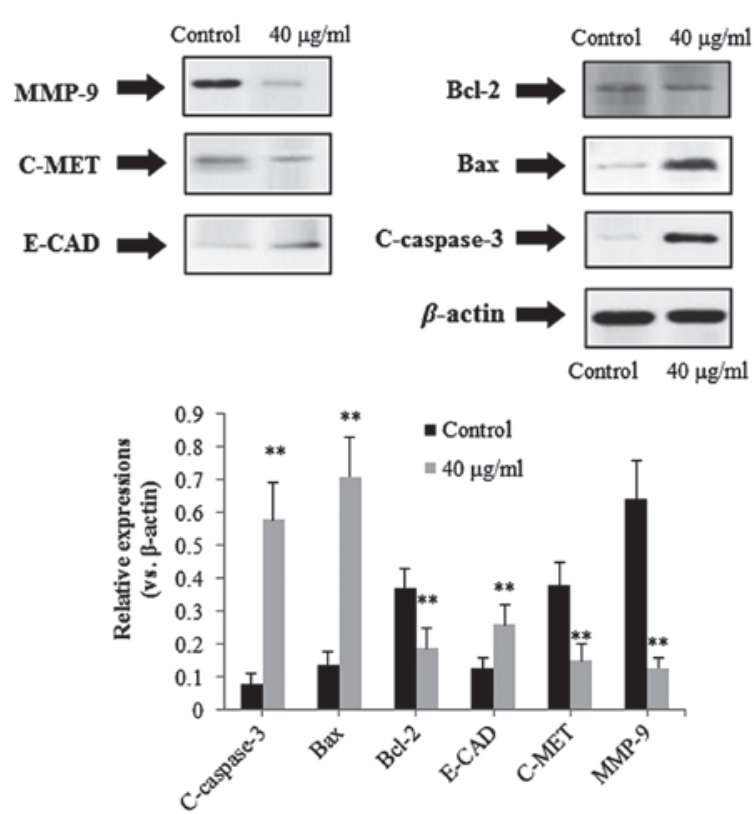

Figure 9. Effects of RSP on caspase-3, Bax, Bcl-2, c-MET, E-CAD and MMP-9 in Cal-27 cells. Cells were treated with RSP $(40 \mu \mathrm{g} / \mathrm{ml})$ for $24 \mathrm{~h}$. Total cell proteins were extracted and subjected to western blot assay using antibodies against caspase-3, Bax, Bcl-2, c-MET, E-CAD and MMP-9, with $\beta$-actin used as an internal control. Results are expressed as the mean \pm standard deviation $(\mathrm{n}=4)$. ${ }^{* *} \mathrm{P}<0.01$ vs. control. RSP, riparsaponin; Bcl-2, B-cell lymphoma 2; Bax, Bcl-2-associated X protein; E-CAD, epithelial cadherin; MMP-9, matrix metalloproteinase 9.

upregulated (Fig. 9). These results confirmed the antitumor effects of RSP on OSCC.

\section{Discussion}

To the best of our knowledge, the present study is the first to investigate the antitumor effect of RSP on human oral carcinoma cells. Results demonstrated that RSP exhibited a notable antitumor effect against human oral carcinoma cells by inducing the intrinsic apoptosis pathway. 
It has been suggested previously that uncontrolled cell proliferation and deregulation of apoptosis may be the primary reason for the occurrence of tumors (17). In addition, evidence is accumulating that apoptosis, a programmed physiological cell suicide process, is considered to be an ideal strategy for inhibiting the development and progression of cancer $(18,19)$. Apoptosis is characterized by distinct morphological changes involving the nucleus (such as pyknosis, chromatin condensation, karyorhexis and nuclear fragmentation), the plasma membrane (phosphatidylserine exposure) and the entire cell progressively shrinks and eventually breaks into a number of 'apoptotic bodies'. Furthermore, apoptosis is regulated by a series of biochemical events and eventually results in cell death $(19,20)$. For apoptosis, there are two major signaling pathways including the extrinsic and the intrinsic pathway. The extrinsic apoptosis pathway is primarily mediated by ligand-bound death receptors of the tumor necrosis factor receptor family, and the intrinsic pathway, called the mitochondria-mediated apoptosis pathway, is activated primarily by mitochondria and the Bcl-2 family. However, the two apoptosis pathways ultimately activate members of the caspase family (19). The present study focused primarily on the mitochondria-mediated apoptosis induced by RSP in oral cancer cells. Caspase-9, first activated by cytochrome $c$ in the cytoplasm, is the initiating caspase protein of the caspase cascade reaction, and the activated caspase-9 subsequently activates the executioner caspase-3. Activated caspase- 3 is commonly considered to be a biomarker for cells undergoing apoptosis (19,21). Proteins in the Bcl-2 family, including Bax, Bad and Bcl-2, have been demonstrated as important members in controlling cytochrome $c$ release in the intrinsic apoptosis pathway (22). Bax and Bad, pro-apoptotic Bcl-2 family members, promote the release of cytochrome $c$ into the cytosol $(19,21)$. In contrast, Bcl-2 is the anti-apoptotic protein that prevents the release of cytochrome $c$ by preserving mitochondrial integrity $(19,20)$. The results of the present study revealed that RSP upregulates C-caspase-3, C-caspase-9, Bad and Bax, and downregulates Bcl-2, leading to mitochondria-mediated apoptosis.

Increasingly, previous research has indicated that metastasis is a primary reason for the recurrence and mortality of patients with OSCC. The process of metastasis is regulated by a variety of genes, such as E-CAD, c-MET, MMP-2 and MMP-9. E-CAD, a membranous glycoprotein, exerts important effects in the maintenance of cell-cell adhesion, epithelial tissue polarity preservation and structural integrity (23-25). Epidemiological studies have identified that the expression of E-CAD is commonly downregulated in OSCC, thus decreased E-CAD levels may be considered an indicator of unfavorable prognosis in OSCC (24). c-MET, a transmembrane tyrosine kinase receptor is commonly recognized as a crucial factor for mediating the oncogenic activities of hepatocyte growth factor. Upregulation of c-MET has been reported to contribute to the progression and dissemination of various malignancies (26). MMPs, a family of zinc-dependent proteinases, are able to degrade the majority of the extracellular matrix components $(27,28)$. In the development of malignancies, activated MMPs may promote the degradation of extracellular matrix, movement of tumor cells and tumor growth, which are directly associated with invasion, metastasis and poor prognosis of malignancies. Previous studies have demonstrated that MMP-2 and MMP-9 are commonly upregulated in various types of malignant tissues $(2,29,30)$. Results of the present study revealed that RSP downregulates E-MET, MMP-2 and MMP-9, whereas RSP upregulates E-CAD, indicating that RSP exhibits inhibitory potential on the metastasis of OSCC.

The results of the present study demonstrated that RSP exhibited significant antitumor activity against OSCC via inducing mitochondria-mediated apoptosis.

\section{References}

1. Huang HZ and Wang C: Molecular mechanisms of invasion-metastasis cascade in oral cancer. J Oral Maxil Surg 20: 77-82, 2011.

2. Kaomongkolgit R, Cheepsunthorn P, Pavasant $P$ and Sanchavanakit N: Iron increases MMP-9 expression through activation of AP-1 via ERK/Akt pathway in human head and neck squamous carcinoma cells. Oral Oncol 44: 587-594, 2008.

3. Siegel R, Naishadham D and Jemal A: Cancer statistics, 2012. CA Cancer J Clin 62: 10-29, 2012.

4. Malik UU, Zarina S and Pennington SR: Oral squamous cell carcinoma: Key clinical questions, biomarker discovery, and the role of proteomics. Arch Oral Biol 63: 53-65, 2016.

5. Acharya S, Rai P, Hallikeri K, Anehosur V and Kale J: Serum lipid profile in oral squamous cell carcinoma: Alterations and association with some clinicopathological parameters and tobacco use. Int J Oral Maxillofac Surg 45: 713-720, 2016.

6. Abe S, Oikawa M, Miki Y, Shimizu Y, Suzuki T, Takahashi T and Kumamoto H: Immunohistochemical and genetic evaluations of epidermal growth factor receptor (EGFR) in oral squamous cell carcinoma. J Oral Maxillofac Surg Med Pathol 28: 174-181, 2016.

7. Gohulkumar M, Gurushankar K, Rajendra Prasad N and Krishnakumar N: Enhanced cytotoxicity and apoptosis-induced anticancer effect of silibinin-loaded nanoparticles in oral carcinoma (KB) cells. Mater Sci Eng C Mater Biol Appl 41: 274-282, 2014.

8. Chen L, Zeng R and Zhuang Y: In vitro anti-gastric tumor activities and possible mechanisms of action of paederosidic acid from Paederia scandens (Lour) Merrill. Trop J Pharm Res 14: 795-800, 2015.

9. Kinghorn AD, Chin YW and Swanson SM: Discovery of natural product anticancer agents from biodiverse organisms. Curr Opin Drug Discov Devel 12: 189-196, 2009.

10. Peng W, Hu C, Shu Z, Han T, Qin L and Zheng C: Antitumor activity of tatariside $\mathrm{F}$ isolated from roots of Fagopyrum tataricum (L.) Gaertn against H22 hepatocellular carcinoma via up-regulation of p53. Phytomedicine 22: 730-736, 2015.

11. Liu P, Yang H, Long F, Hao HP, Xu X, Liu Y, Shi XW, Zhang DD, Zheng HC, Wen QY, et al: Bioactive equivalence of combinatorial components identified in screening of an herbal medicine. Pharm Res 31: 1788-1800, 2014.

12. Wu WY, Hou JJ, Long HL, Yang WZ, Liang J and Guo DA: TCM-based new drug discovery and development in China. Chin J Nat Med 12: 241-250, 2014.

13. Lee I, Kim J, Kim YS, Yoo NH, Kim CS, Jo K, Kim JH, Bach TT and Kim JS: Cycloartane-type triterpenes from the leaves of Homonoia Riparia with VEGF-induced angiogenesis inhibitor activity. J Nat Prod 75: 1312-1318, 2012.

14. State Administration of Traditional Chinese Medicine. Chinese Material Medica; Science and Technology Press of Shanghai: Shanghai, China 6: 824-825, 1999.

15. Viswanadh GS, Ramaiah PA, Laatsch H and Maskey R: Chemical constituents of the heartwood and bark of Homonoia riparia. J Trop Med Plants 7: 267-273, 2006.

16. XuF,Zhao X, Yang L, Wang X and Zhao J: A new cycloartane-type triterpenoid saponin xanthine oxidase inhibitor from Homonoia riparia Lour. Molecules 19: 13422-13431, 2014.

17. Qi F, Li A, Zhao L, Xu H, Inagaki Y, Wang D, Cui X, Gao B, Kokudo N, Nakata M and Tang W: Cinobufacini, an aqueous extract from Bufo bufo gargarizans Cantor, induces apoptosis through a mitochondria-mediated pathway in human hepatocellular carcinoma cells. J Ethnopharmacol 128: 654-661, 2010.

18. Kerr JF, Winterford CM and Harnon BV: Apoptosis. Its significance in cancer and cancer therapy. Cancer 73: 2013-2026, 1994.

19. Wang X: The expanding role of mitochondria in apoptosis. Genes Dev 15: 2922-2933, 2001. 
20. Galluzzi L, Zamzami N, de La Motte Rouge T, Lemaire C, Brenner C and Kroemer G: Methods for the assessment of mitochondrial membrane permeabilization in apoptosis. Apoptosis 12: 803-813, 2007.

21. Shi YG: A structural view of mitochondria-mediated apoptosis. Nat Struct Biol 8: 394-401, 2011

22. Chipuk JE, McStay GP, Bharti A, Kuwana T, Clarke CJ, Siskind LJ, Obeid LM and Green DR: Sphingolipid metabolism cooperates with BAK and BAX to promote the mitochondrial pathway of apoptosis. Cell 148: 988-1000, 2012.

23. Beavon IR: The E-cadherin-catenin complex in tumour metastasis: Structure, function and regulation. Eur J Cancer 36: 1607-1620, 2000.

24. Martínez A, Spencer ML, Borlando J, Flores M and Rojas IG: E-cadherin and c-Met expression in actinic cheilits and lip squamous cell carcinoma. Rev Clin Periodoncia Implantol Rehabil Oral 4: 122-125, 2011.

25. Yang XK, Yang YD, Tang SQ, Xu L, Yang GH, Xu QY, Tang H and $\mathrm{Wu}$ JJ: Inhibitory effect of polysaccharides from Scutellaria barbata D. Don on invasion and metastasis of 95-D cells lines via regulation of C-MET and E-CAD expressions. Trop J Pharm Res 12: 517-522, 2013.
26. Yang L, Liu M, Deng C, Gu Z and Gao Y: Expression of transforming growth factor- $\beta 1$ (TGF- $\beta 1$ ) and E-cadherin in glioma. Tumour Biol 33: 1477-1484, 2012.

27. Qin Y, Ye GX, Wu CJ, Wang S, Pan DB, Jiang JY, Fu J and Xu SQ: Effect of DAPK1 gene on proliferation, migration, and invasion of carcinoma of pancreas BxPC-3 cell line. Int J Clin Exp Pathol 7: 7536-7544, 2014.

28. Sanchavanakit N, Saengtong W, Manokawinchoke J and Pavasant P: TNF- $\alpha$ stimulates MMP-3 production via $\mathrm{PGE}_{2}$ signalling through the NF- $\mathrm{BB}$ and $\mathrm{p} 38$ MAPK pathway in a murine cementoblast cell line. Arch Oral Biol 60: 1066-1074, 2015.

29. Duxbury MS and Whang EE: RRM2 induces NF-kappaB-dependent MMP-9 activation and enhances cellular invasiveness. Biochem Biophys Res Commun 354: 190-196, 2007.

30. Silva EJ, Argyris PP, Zou XQ, Ross KF and Herzberg MC: S100A8/A9 regulates MMP-2 expression and invasion and migration by carcinoma cells. Int J Biochem Cell Biol 55: 279-287, 2014. 